\title{
Effects of culinary treatments on lipids quality, proximate composition and mineral content of broilers meat fed with rations supplemented with powders of Camellia sinensis, Annona muricata and Zingiber officinale
}

\author{
${ }^{1}$ Ndomou, S.C.H., ${ }^{1,2}$ Tonfack Djikeng, F., ${ }^{1}$ Tiwo, C.T., ${ }^{1}$ Teboukeu, G.B. and ${ }^{1 *}$ Womeni, \\ H.M. \\ ${ }^{1}$ Laboratory of Biochemistry of Medicinal plants, Food Sciences, and Nutrition, Department of \\ Biochemistry, Faculty of Science, University of Dschang, Cameroon. P.O. Box 67 Dschang, Cameroon. \\ ${ }^{2}$ School of Agriculture and Natural Resources, Catholic University Institute of Buea, P.O. Box 563 Buea, \\ Cameroon
}

\author{
Article history: \\ Received: 21 February 2018 \\ Received in revised form: 22 \\ March 2018 \\ Accepted: 23 March 2018 \\ Available Online: 01 April \\ 2018
}

\section{Keywords:}

Broiler meat,

Camellia sinensis,

Annona muricata,

Zingiber officinale,

Cooking treatments,

Lipids quality

DOI:

https://doi.org/10.26656/fr.2017.2(4).055

\begin{abstract}
This study aimed to evaluate the effects of feeding system and cooking treatments on the lipids quality, proximate composition and mineral content of broiler meat (thigh muscle) fed with powders of three natural plants. Hundred (100) twenty-one-day-old broiler chickens (Cobb 500) were randomly allocated to five (5) experimental diets with 10 replicates consisting of the basic ration (without antioxidant) from which four other feeds were obtained by adding $200 \mathrm{UI} / \mathrm{kg}$ of Vitamin E (VitE); $5 \mathrm{~g} / \mathrm{kg}$ of tea leaves powder (CS); Ginger root powder (ZO) and Soursop flowers powder (AM). Feed and water were supplied ad libitum throughout the experimental period. On the $49^{\text {th }}$ day, they were randomly slaughtered, and their carcasses were collected for culinary treatments. Thereafter, lipids were extracted from the meat using the method described by Bligh and Dyer. Their quality was assessed by the determination of peroxide value (PV), thiobarbituric acid reactive substances value (TBARS) and acid value (AV); while the proximate composition and mineral content were performed on meat flours. Results revealed that the treatments $\mathrm{Raw}+\mathrm{ZO} ; \mathrm{Fr}+\mathrm{AM} ; \mathrm{Fr}+\mathrm{ZO} ; \mathrm{Bo}+\mathrm{CS} ; \mathrm{Bo}+\mathrm{ZO}$ and $\mathrm{Bo}+\mathrm{AM}$ limited the formation of hydroperoxides. Except for the treatment $\mathrm{Fr}+\mathrm{AM}$, all the treatments significantly increased $(\mathrm{P}<0.05)$ the level of TBARS. Combined treatments increased AV. Plant supplementation enhances the nutritional value of broiler meat. Thus, the supplementation of broiler ration with natural powders might be a good alternative to maintain the lipids stability of broiler meat and enhance their nutritional value during cooking treatments.
\end{abstract}

\section{Introduction}

The production of meat is increasing highly and the sector of monogastric animals is more concerned where the production of poultry meat is most representatives. Consumption of poultry meat is constantly increasing and nutrition of meat quality depends mainly on poultry feed composition's (Schwartzkopf-Genswein et al., 2012). Poultry meat is among the most popular meats in the world owing because of its low price, short production time and ease preparation (Chouliara et al., 2007).

However, broiler meat possesses a higher amount of polyunsaturated fatty acids that are susceptible to oxidative degradation, leading to lower consumer acceptability for broiler meat products (Sohaib et al.,
2017). Besides these deteriorations, lipid oxidation also generates cytotoxic and genotoxic compounds which are deleterious to humans health (Botsoglou et al., 2014). Some problems in meat and meat-based products such as tissues damaging, loss of nutrients, putrification, malonaldehydes production and enhancement of free radicals generation are caused by oxidative damage that reduce the antioxidant capacity of products (Ahn et al., 2009).

The stability of meat lipids mainly depends on the balance of antioxidants, oxidation substrate and cholesterol content as well as heme pigment. Using antioxidant based formulation in animal feeding can be important to control oxidative process in meat and meat products. These help in disruption of the oxidation chain 
reaction that further progress with a passage of time which ultimately reduces the quality of meat-based products (Ennajar et al., 2009). However, according to Altmann et al. (1986) synthetic antioxidants such as butylated hydroxyanisole (BHA) and butylated hydroxytoluene (BHT) that are generally used to slow or minimize oxidative deterioration of foods have been rejected because of their carcinogen effects.

Nowadays, the increasing preference for natural foods has obliged agrifood industries to incorporate natural antioxidants in various products in order to replace synthetic antioxidants, limit oxidative degradation of lipids and improve their nutritional values (Camo et al., 2008). Dietary supplementation of $\alpha$ tocopherol in poultry meat was found to be one of pragmatic choice to improve the oxidative stability of lipids and inhibiting oxidation of cholesterol in meat. Adding $\alpha$-tocopherol in feed protects the broiler chicken against a stress-induced increase in thiobarbituric acid reactive substances (TBARS) by limiting oxidation as well as preserving animal health. It also enhances stability and quality of lipids in chicken muscles when added in the diet (Li et al., 2009). According to Sohaib et al. (2012), incorporation of $\alpha$-tocopherol at $200 \mathrm{IU} / \mathrm{Kg}$ level is considered effective to increase the oxidative stability of broiler meat. Including $\alpha$-tocopherol in livestock diets presented significant effects on the oxidative activities of their tissues and stability of meat products (Boler et al., 2009; Lahucky et al., 2010). Extracts or essential oils from several herbal plants including rosemary, ginger and sage (Lopez-Bote et al., 1998), tea (Tang et al., 2001), and oregano (Botsoglou et al., 2003; Giannenas et al., 2005) have been shown to have the capacity to ameliorate growth performance and increase the antioxidant capacity of poultry meat when supplemented in feeds. Recently, a study revealed that methanolic extract of soursop flowers (Annona muricata) is rich in vanillic acid, caffeic acid, ferulic acid, ellagic acid, and quercetin. These compounds have shown a good lipid stability of palm olein during accelerated storage of 30 days at $70^{\circ} \mathrm{C}$ (Womeni, Djikeng, Anjaneyulu et al., 2016). The quercetin is a type of flavonol belonging to the class of flavonoids, present in vegetables and fruits especially red onion, caper, apple, in some medicinal and aromatic plants (Bhagwat et al., 2013). Quercetin is a powerful antioxidant capable of reducing lipid peroxidation in meat-based products by limiting the oxidation chain reaction. The antioxidant activity of quercetin is attributed to its ability to scavenge free radicals, chelate metal cations and donate hydrogen atoms or electrons. Also, various studies conducted in vitro and in vivo in experimental animals showed that quercetin has antioxidant and antiinflammatory properties (Bodas et al., 2011). Ginger
(Zingiber officinale), contains relatively large amounts of volatile oils camphene, alpha-terpineol, p-cineole, zingiberene, and pentadecanoic acid (El-Ghorab et al., 2010) both in the fresh and dried form. Ginger extracts revealed antioxidant activity almost equal to that of synthetic antioxidants such as BHA and BHT (Rehman et al., 2003).

This study aimed at evaluating the effects of dietary supplementation by natural sources of antioxidants (flowers of Annona muricata; roots of Zingiber officinalis and leaves of Camellia sinensis) and cooking treatments on lipids quality, proximate composition and mineral content in broiler meat in order to improve food security and consumers health.

\section{Material and methods}

\subsection{Plants preparation}

Fresh leaves of Camellia sinensis and flowers of Annona muricata were collected respectively at Bafou and Santchou Divisions, Cameroon; while the roots of Zingiber officinale were purchased at the local market of Dschang, Menoua Division, Cameroon. After collection, they were cleaned and dried at $45^{\circ} \mathrm{C}$ in an oven during $48 \mathrm{~h}$. The dried plant samples were grounded to obtain fine powders which were kept in a desiccator for further use.

\subsection{Animal's experimental design}

One hundred 21-day-old broiler chicks ( $C o b b 500$ ) with an average weight of $550 \mathrm{~g}$ were used, they were randomly assigned in cages of $50 \mathrm{~cm}$ (length) $\times 50 \mathrm{~cm}$ (width) $\times 50 \mathrm{~cm}$ (height) previously washed and disinfected. Each cage consisted of two broilers (male and female) receiving the 5 treatment groups, with 10 replicates per treatment. From a control diet without any supplement $(\mathrm{CO})$, four other rations were obtained by adding to the $200 \mathrm{UI} / \mathrm{kg}$ of VitE (VitE); $5 \mathrm{~g} / \mathrm{kg}$ of tea leaves (Camellia sinensis) dried powder (CS); $5 \mathrm{~g} / \mathrm{kg}$ Ginger root (Zingiber officinale) dried powder (ZO) and $5 \mathrm{~g} / \mathrm{kg}$ soursop flowers (Annona muricata) dried powder (AM) (Table 1). Feed and water were supplied ad libitum throughout the experimental period and for sanitation, drinkers were washed every day. Chicks were vaccinated against Gumboro Disease, Newcastle Disease at day 8, 14 and day 21, respectively in the drinking water. On the $49^{\text {th }}$ day, 8 broilers (per treatment) were randomly selected, fate for $24 \mathrm{~h}$ and slaughtered by cervical dislocation. Feathers were plucked using boiling water and eviscerated manually. The carcass was collected and used for culinary treatments.

\subsection{Culinary treatments of broiler meat}




\subsubsection{Cooking by boiling}

Boiling was performed at $100 \pm 5^{\circ} \mathrm{C}$ and $200 \mathrm{~g}$ of sample (thigh without bone) were boiled in $1400 \mathrm{ml}$ water for 30 min using a domestic stainless-steel pot on a hotplate.

\subsubsection{Cooking by frying}

For this treatment, $200 \mathrm{~g}$ (thigh without bone) of each ration were weighed, and placed in one liter of refined palm oil (Mayor) heated for $5 \mathrm{~min}$ in a deep fryer (HQ brand). Frying was done at $180^{\circ} \mathrm{C}$ minimum for 15 min and the meat was turned after every $3 \mathrm{~min}$. The Mayor oil (purchased at the local market) was used because of its high saturated fatty acids content, thereby limiting oxidation reactions during the treatment. The oil was replaced after each frying.

\subsubsection{Cooking by frying and boiling}

The meat obtained after frying under the same conditions as stated above was introduced into $1400 \mathrm{ml}$ of boiling water (initial boiling point of $95^{\circ} \mathrm{C}$ ) and the treatment was carried out for $10 \mathrm{~min}$ on a hotplate.

Table 1. Feed ingredients and proximate nutrients composition of experimental diets

\begin{tabular}{lcc}
\hline \multirow{2}{*}{ Ingredients (Kg) } & \multicolumn{2}{c}{ Periods } \\
\cline { 2 - 3 } & $\begin{array}{c}\text { Brooding } \\
\left(1^{\text {st }}-21^{\text {st }} \text { day }\right)\end{array}$ & $\begin{array}{c}\text { Finisher } \\
\left(22^{\text {nd }}-49^{\text {th }}\right.\end{array}$ day $)$ \\
\hline Corn & 59 & 60 \\
wheat bran & 03 & 08 \\
Soybean crab & 23 & 13 \\
Premix 5\% & 05 & 05 \\
Shell & 01 & 01 \\
Cotton & 03 & 05 \\
Palm oil & 01 & 1.5 \\
Fish meal & 05 & 6.5 \\
Total (Kg) & 100 & 100 \\
\hline
\end{tabular}

Calculated proximate nutrients composition

\begin{tabular}{lcc}
\hline Metabolizable & 2961.71 & 3005.80 \\
Energy (kcal/kg) & 23.32 & 20.54 \\
Crude Protein (\%) & 126.98 & 146.37 \\
Energy/protein & 1.4 & 1.20 \\
ratio & 0.48 & 0.45 \\
Lysine (\%) & 1.11 & 1.32 \\
Methionine (\%) & 0.54 & 0.58 \\
Calcium (\%) & 4.76 & 4.91 \\
Phosphorus (\%) & \\
Crude fiber (\%) &
\end{tabular}

Premix 5\%: crude proteins $=40 \%$, Lys $=3.3 \%$, Meth $=$ $2.40 \%, \quad \mathrm{Ca}=8 \%, \quad \mathrm{P}=2.05 \%, \quad$ Metabolizable energy $=2078 \mathrm{kcal} / \mathrm{kg}$

\subsection{Lipid extraction}

Fat was extracted from raw and cooked broiler meat according to the method described by Bligh and Dyer (1959) using a combination of Chloroform and Methanol (2:1). The extracted oil samples were stored at $-4^{\circ} \mathrm{C}$ for chemical analysis.

\subsection{Lipids oxidation assessment}

The peroxide value of oils extracted from the different samples was determined using the spectrophotometric IDF standard method, 74A (1991). Its acid value was determined according to the procedure of AOCS Official Method CD 3d-63 (AOCS, 2003). Secondary oxidation products were evaluated using thiobarbituric acid value as described by Draper and Hadley (1990).

\subsection{Proximate composition analysis}

For proximate composition, samples obtained for fresh and cooked meat was previously dried in an oven at $45^{\circ} \mathrm{C}$ during 12 hours and they were reduced to powder using a kitchen blender. Moisture, fat, ash, and protein content of fresh and cooked meat samples were determined using standard analytical methods described by AOAC procedures (AOAC, 1990). Moisture content was determined by drying meat sample in an oven at $105 \pm 2^{\circ} \mathrm{C}$ until a constant weight was achieved according to the AOAC procedures 925.40 (AOAC, 1990). For the cooked samples, the moisture content was determined on the meat flours. Ash content was determined by incineration of the sample for $20 \mathrm{~h}$ at $550^{\circ} \mathrm{C}$ according to the AOAC procedures 942.05 (AOAC, 1990). Nitrogen (N) content was determined using the micro-Kjeldahl method, according to AOAC procedures 984.13 (AOAC, 1990), the protein content was calculated as $\mathrm{N} \times 6.25$. Lipid content was determined using Soxhlet apparatus with hexane, following AOAC 963.15 methodology (AOAC, 1990). The total percentage carbohydrate content was determined by the difference method as reported by Onyeike et al. (2015). This method involved adding the total values of crude protein, crude fat, moisture and ash constituents of the sample and subtracting it from 100. All samples were analyzed in triplicate.

\subsection{Mineral analysis}

Some main minerals ( $\mathrm{Ca}, \mathrm{Na}, \mathrm{K}, \mathrm{P}$, and $\mathrm{Mg}$ ) and some trace minerals ( $\mathrm{Fe}$ and $\mathrm{Zn}$ ) were analyzed in fresh and cooked meat sample. For mineral analysis accurately weighed ash samples were boiled with $10 \mathrm{ml}$ of $20 \%$ $\mathrm{HCl}$ in a beaker and then filtered into a $100 \mathrm{ml}$ standard flask to determine the mineral content. Mineral content of the digested samples was determined by flame atomic 
absorption spectrophotometry using a Varian 220FS Spectra AA apparatus for calcium $(\mathrm{Ca})$, magnesium $(\mathrm{Mg})$, sodium $(\mathrm{Na})$, potassium $(\mathrm{K})$, zinc $(\mathrm{Zn})$ and iron $(\mathrm{Fe})$, while phosphorus (P) was determined by spectrophotometric colorimetric method using UV spectrophotometer according to AOAC procedure 965.17 (AOAC, 1999). Mineral contents of the samples were determined from calibration curves of standards minerals. All samples were analyzed in triplicate.

\subsection{Statistical analysis}

Results obtained were subjected to analysis of variance (ANOVA) with Newman-Keuls Multiple Comparison Test, to evaluate the statistical significance of the data expressed as mean \pm standard deviations. A probability value of $p<0.05$ was considered statistically significant using GraphPad Prism 5 software.

\section{Results and discussion}

\subsection{Effects of treatments on the peroxide value}

The peroxide value (PV) measures the number of hydroperoxide products and is used to evaluate the oxidative state of lipid-containing foods (Juntachote et al., 2007). The PV data is presented in Figure 1. The treatments Raw $+\mathrm{ZO}\left(2.11 \pm 0.04\right.$ meq $\left.\mathrm{O}_{2} / \mathrm{Kg}\right) ; \mathrm{Fr}+\mathrm{AM}$ $\left(2.51 \pm 0.00 \mathrm{meq} \mathrm{O}_{2} / \mathrm{Kg}\right) ; \mathrm{Fr}+\mathrm{ZO}\left(2.65 \pm 0.06 \mathrm{meq} \mathrm{O}_{2} / \mathrm{Kg}\right)$; $\mathrm{Bo}+\mathrm{CS}\left(3.75 \pm 0.44 \mathrm{meq} \mathrm{O}_{2} / \mathrm{Kg}\right) ; \mathrm{Bo}+\mathrm{ZO}(5.49 \pm 0.39 \mathrm{meq}$ $\left.\mathrm{O}_{2} / \mathrm{Kg}\right)$ and $\mathrm{Bo}+\mathrm{AM} \quad\left(8.08 \pm 0.45\right.$ meq $\left.\mathrm{O}_{2} / \mathrm{Kg}\right)$ significantly decreased $(\mathrm{p}<0.05)$ the $\mathrm{PV}$ in oil extracted on thigh meat than the other treatments. These observations could be due to the presence of natural antioxidant substances in broiler food that have limited the production of hydroperoxides in these treatments at that concentration. It was revealed that extract of Annona muricata is rich in vanillic acid, caffeic acid, ferulic acid, ellagic acid, and quercetin and extract of Camellia sinensis are rich in gallic acid, epicatechin gallate, gallocatechin and epigallocatechin gallate (Womeni, Djikeng, Anjaneyulu et al., 2016; Womeni, Tonfack, Prabhakar et al., 2016). Also, it might also due to the transformation of hydroperoxides; which are unstable intermediate substances, to secondary oxidation products which are responsible for the changes in odor and flavor of rancid fats (Shermer, 1990). According to CODEX standards (2015), the maximum limit recommended for animal's fat is 10 millieq of active $\mathrm{O}_{2} / \mathrm{kg}$; so, the above treatments had preserved this indicator. However, all the treatments supplemented with vitamin $\mathrm{E}$ as synthetic antioxidant presented a high PV than the above treatment. This might be due to the less integration during feeding. Also, high amounts of PV were generally observed in the both treatments and this might be due to the high temperature that had inhibited the activities of antioxidants and allowed the formation of hydroperoxides. These results were in agreements with Song et al. (2010), which reported that PV of tallow reached a high level when heated at $140^{\circ} \mathrm{C}$ for 2 hours.

\subsection{Effects of treatment on the thiobarbituric acid reactive substances}

Peroxidation of lipids is one of the major mechanisms of quality modification in foods. It occurs when hydroxyl radicals attack fatty acid side chains of membrane phospholipids. Malondialdehyde (MDA) is a product of lipid peroxidation and TBARS, as indicated by the MDA concentration, serving as oxidative damage index. The changes in quality contribute to the deterioration of nutritive value, flavor, color, and texture of the food due to the production of toxic compounds (Mohamed et al., 2008).

The results show that thiobarbituric acid reactive substances (TBARS) of the broiler thigh meat presented significant differences $(p<0.05)$ due to the cooking treatments (Figure 2). The lowest TBARS of thigh meat was recorded in the treatments: Fr+AM $(2.457 \pm 0.01 \mathrm{mg}$ $\mathrm{MDA} / \mathrm{kg}$ ), followed by Bo+CS $(3.58 \pm 0.304 \mathrm{mg} \mathrm{MDA} /$ $\mathrm{kg})$ and Fr+VitE $(4.32 \pm 0.027 \mathrm{mg} \mathrm{MDA} / \mathrm{kg})$; while the majority of highest TBARS values were obtained with Boiling and combination of treatments. Also, in these treatments, the TBARS values recorded were significantly lower $(\mathrm{p}<0.05)$ than the raw sample. The lowest values observed in different treatments could be due to the action of compounds such as quercetin and $\alpha$ tocopherol that have limited lipids deterioration. Indeed, quercetin is a powerful antioxidant capable of reducing lipid peroxidation in meat-based products by limiting oxidation chain reaction. The antioxidant activity is attributed to its ability to scavenge free radicals, chelate metal cations and donate hydrogen atoms or electrons (Bodas et al., 2011). Also, it has been shown that $\alpha$ tocopherol is a lipid-soluble antioxidant that belongs to tocopherol family which cannot be synthesized by the animal cells and plays a role in the protection of membrane against oxidation (D'Arrigo et al., 2002). According to Barroeta (2007), feed supplementation with $\alpha$-tocopherol in animals increased the deposition of lipoic acid as an increase in its concentration and the level of vitamin $\mathrm{E}$ in the muscle depends on its dietary level, the duration of the supplementing period, the fiber type distribution and on a metabolic characteristic. Previous studies revealed that quercetin and $\alpha$-tocopherol were able to attenuate lipid peroxidation process in birds (Goliomytis et al., 2014). Haak et al. (2009) showed that $\alpha$-tocopherol alone or in combination with rosemary and green tea extract retarded retards lipid oxidation in meat.

However, according to Greene and Cumuze (1982), 


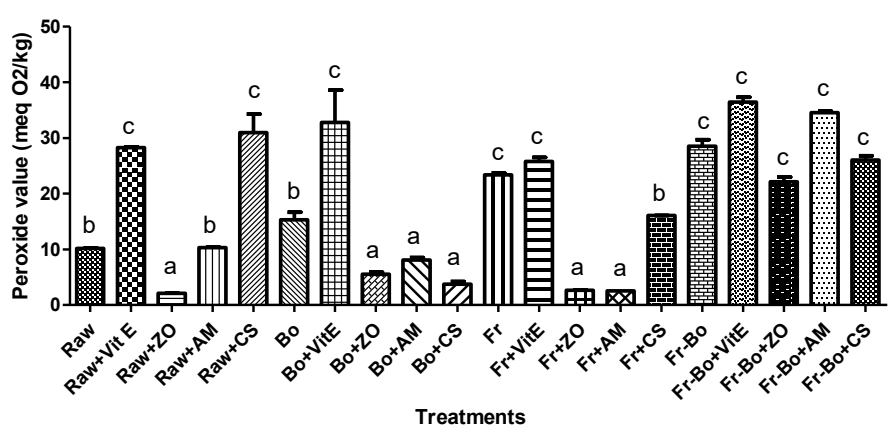

Figure 1. Peroxide value in thigh meat of broilers.

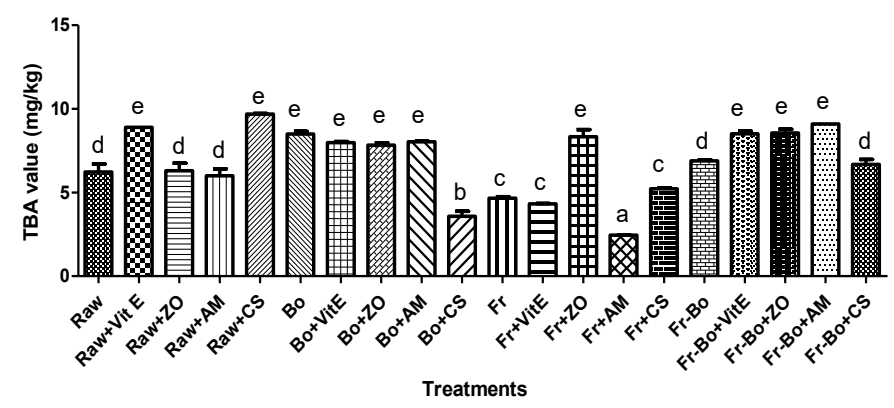

Figure 2. Thiobarbituric acid reactive substances in thigh meat of broilers

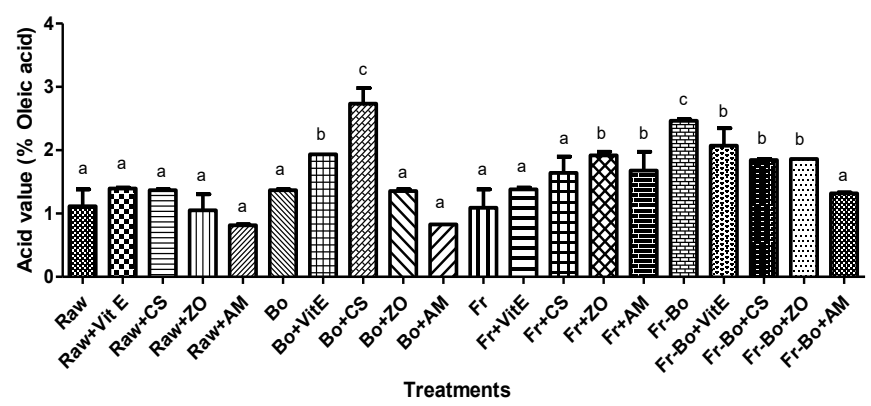

Figure 3. Acid value in thigh meat of broilers

Results are means \pm standard error $(n=3)$. The column diagram with different letters differs significantly $(\mathrm{p}<0.05)$. Raw $=$ Raw meat; Raw + VitE = broiler reared with 200 UI of vitamin E, Raw $+Z$ O = broiler reared with $5 \mathrm{~g} / \mathrm{kg}$ of Zingiber officinale, $\mathrm{Raw}+\mathrm{AM}=$ broiler reared with $5 \mathrm{~g} / \mathrm{kg}$ of Annona muricata , Raw $+\mathrm{CS}=$ broiler reared with $5 \mathrm{~g} / \mathrm{kg}$ of Camellia sinensis, Bo = Boiled meat, $\mathrm{Bo}+\mathrm{VitE}=$ Boiled meat reared with $200 \mathrm{UI}$ of vitamin $\mathrm{E}$; Bo+ZO = Boiled meat reared with $5 \mathrm{~g} / \mathrm{kg}$ of Zingiber officinale, $\mathrm{Bo}+\mathrm{AM}=$ Boiled meat reared with $5 \mathrm{~g} / \mathrm{kg}$ of Annona muricata, Bo $+\mathrm{CS}=$ Boiled meat reared with $5 \mathrm{~g}$ of Camellia sinensis; $\mathrm{Fr}=$ Fried meat, Fr+ VitE = Fried meat reared with $200 \mathrm{UI}$ of vitamin E, Fr+ZO = Fried meat reared with5g/kg of Zingiber officinale $; \mathrm{Fr}+\mathrm{AM}=$ Fried meat reared with $5 \mathrm{~g} / \mathrm{kg}$ of Annona muricata, $\mathrm{Fr}+\mathrm{CS}=$ Fried meat reared with5g/ $\mathrm{kg}$ of Camellia sinensis, Fr-Bo $=$ Fried and boiled meat, Fr-Bo+VitE $=$ Fried and boiled meat reared with 200 UI of vitamin, Fr- Bo $+\mathrm{ZO}=\mathrm{Fried}$ and boiled meat reared with $5 \mathrm{~g} / \mathrm{kg}$ of Zingiber officinale, Fr-Bo+AM = Fried and boiled meat reared with $5 \mathrm{~g} / \mathrm{kg}$ of Annona muricata and $\mathrm{Fr}-\mathrm{Bo}+\mathrm{CS}=$ Fried and boiled meat reared with $5 \mathrm{~g} / \mathrm{kg}$ of Camellia sinensis.

the maximum acceptable limit of TBARS in a dietary product is $2.0 \mathrm{mg} \mathrm{MA} / \mathrm{kg}$ and this was is due to its relation to off-odor appearance. The high levels of TBARS values obtained in our study could be due the animal part used and the heat treatments applied. Chen et al. (2011) reported that MDA values found in leg meat were greater than those in breast meat because leg meat had a greater percentage of polyunsaturated fatty acids than breast meat. Also, Sohaib et al. (2015) observed that cooking process depleted quercetin in broiler meat after cooking during $30 \mathrm{~min}$ and this could lead to the increase of TBARS level in meat.

\subsection{Effects of treatments on the acid value}

Acid value (AV) allows the determination of free fatty acid (FFA) generally expressed as a percentage of oleic acid in oil samples. The increase in AV might be an important measure of rancidity of foods. Free fatty acids are formed due to hydrolysis of triglycerides and may get promoted by reaction of oil with moisture (Frega et al., 1999). The changes in the acidity of broiler meat oil during culinary treatments are shown in Figure 3. FFA content of broiler meat increased significantly in the cooking methods evaluated, with a high value obtained with the treatment: Bo+CS (2.73\%); Fr-Bo (2.46\%); Fr$\mathrm{Bo}+\mathrm{VitE}(2.07 \%)$; Bo+VitE (1.93\%) and $\mathrm{Fr}+\mathrm{ZO}$ (1.91\%) while lower values were observed in the treatments Raw+AM (0.81\%); Bo+AM (0.82\%) and Raw+ZO $(1.05 \%)$. This could be explained by the breakdown of ester bonds of triglycerides by the heating process. During frying, the very high temperature involves a further breakdown of ester bonds of triglycerides present in oil by thermolysis. These results were closed to those of Labuza (1974), who revealed that a very high temperature could lead to a higher FFA content due to a strong hydrolysis of esters bonds of triglycerides. Also, Lin et al. (2011) showed that the percentage of acidity on minced pork increases with the temperature and the duration of cooking. During boiling, heating water catalyses the hydrolysis of ester bonds of triglycerides and releases free fatty acids in oil. Similar results have been obtained by Hernandez et al. (1999), they showed that the boiling of the pig meat increases its free fatty acid content and they allocated that to the hydrolysis of triglycerides. So, we observed that frying and frying followed by boiling increased AV of broiler meat oils and this was also observed with the PV and TBARS; and this can be explained by the transformation of FFA to second oxidation products such as peroxide and 
Table 2. Changes in the proximate composition of broiler meat during culinary treatments

\begin{tabular}{|c|c|c|c|c|c|}
\hline Samples & Moisture (\%) & Protein $(\%)$ & Lipids (\%) & $\operatorname{Ash}(\%)$ & Carbohydrate $(\%)$ \\
\hline Raw & $59.44 \pm 3.54^{\mathrm{c}}$ & $31.65 \pm 0.63^{b}$ & $54.17 \pm 0.24^{\mathrm{f}}$ & $6.20 \pm 0.60^{c}$ & $7.97 \pm 0.28^{b}$ \\
\hline Raw + VitE & $70.60 \pm 0.39^{d}$ & $41.69 \pm 0.39^{d}$ & $39.64 \pm 0.55^{\mathrm{c}}$ & $13.70 \pm 0.80^{\mathrm{d}}$ & $4.96 \pm 1.75^{b}$ \\
\hline Raw + CS & $64.57 \pm 0.25^{\mathrm{d}}$ & $43.77 \pm 0.68^{\mathrm{e}}$ & $41.64 \pm 0.21^{\mathrm{c}}$ & $15.25 \pm 0.25^{\mathrm{e}}$ & $0.47 \pm 0.00^{\mathrm{a}}$ \\
\hline $\mathrm{Raw}+\mathrm{ZO}$ & $68.80 \pm 1.25^{\mathrm{d}}$ & $41.17 \pm 0.66^{\mathrm{d}}$ & $35.63 \pm 0.19^{c}$ & $13.75 \pm 0.75^{\mathrm{d}}$ & $9.44 \pm 1.21^{\mathrm{b}}$ \\
\hline $\mathrm{Raw}+\mathrm{AM}$ & $74.66 \pm 1.81^{\mathrm{d}}$ & $26.88 \pm 0.32^{\mathrm{a}}$ & $55.24 \pm 3.58^{\mathrm{f}}$ & $8.20 \pm 0.30^{\mathrm{c}}$ & $9.67 \pm 3.60^{b}$ \\
\hline Bo & $8.78 \pm 0.98^{\mathrm{a}}$ & $41.21 \pm 0.70^{\mathrm{d}}$ & $49.00 \pm 2.38^{\mathrm{d}}$ & $1.25 \pm 0.25^{\mathrm{a}}$ & $8.53 \pm 3.33^{b}$ \\
\hline $\mathrm{Bo}+\mathrm{VitE}$ & $10.78 \pm 0.1^{\mathrm{b}}$ & $46.46 \pm 1.13^{\mathrm{f}}$ & $35.32 \pm 0.81^{\mathrm{c}}$ & $4.35 \pm 0.15^{b}$ & $13.86 \pm 2.09^{b}$ \\
\hline $\mathrm{Bo}+\mathrm{CS}$ & $8.18 \pm 0.22^{\mathrm{a}}$ & $48.25 \pm 1.00^{\mathrm{f}}$ & $34.93 \pm 1.19^{c}$ & $4.1 \pm 0.10^{\mathrm{b}}$ & $12.71 \pm 2.10^{\mathrm{b}}$ \\
\hline $\mathrm{Bo}+\mathrm{ZO}$ & $11.30 \pm 0.42^{b}$ & $36.18 \pm 0.74^{\mathrm{c}}$ & $51.61 \pm 0.73^{\mathrm{e}}$ & $0.70 \pm 0.10^{\mathrm{a}}$ & $11.50 \pm 1.57^{\mathrm{b}}$ \\
\hline $\mathrm{Bo}+\mathrm{AM}$ & $10.62 \pm 0.11^{b}$ & $48.60 \pm 0.65^{\mathrm{f}}$ & $33.36 \pm 0.42^{c}$ & $8.20 \pm 0.20^{c}$ & $9.82 \pm 1.28^{\mathrm{b}}$ \\
\hline Fr & $11.44 \pm 0.1^{\mathrm{b}}$ & $43.31 \pm 0.61^{\mathrm{e}}$ & $34.74 \pm 0.23^{\mathrm{c}}$ & $5.65 \pm 0.25^{\mathrm{c}}$ & $16.29 \pm 0.63^{b}$ \\
\hline $\mathrm{Fr}+\mathrm{VitE}$ & $8.23 \pm 0.44^{\mathrm{a}}$ & $39.68 \pm 0.13^{d}$ & $25.14 \pm 0.09^{\mathrm{a}}$ & $6.45 \pm 0.85^{\mathrm{c}}$ & $28.72 \pm 0.62^{\mathrm{c}}$ \\
\hline $\mathrm{Fr}+\mathrm{CS}$ & $8.04 \pm 0.04^{\mathrm{a}}$ & $40.31 \pm 0.63^{\mathrm{d}}$ & $28.86 \pm 1.05^{\mathrm{b}}$ & $4.40 \pm 0.40^{b}$ & $26.41 \pm 0.02^{c}$ \\
\hline $\mathrm{Fr}+\mathrm{ZO}$ & $13.09 \pm 0.1^{\mathrm{b}}$ & $39.94 \pm 1.00^{\mathrm{d}}$ & $27.51 \pm 0.15^{\mathrm{b}}$ & $3.35 \pm 0.25^{\mathrm{b}}$ & $29.18 \pm 0.90^{c}$ \\
\hline $\mathrm{Fr}+\mathrm{AM}$ & $8.81 \pm 0.28^{\mathrm{a}}$ & $49.92 \pm 0.66^{\mathrm{f}}$ & $38.14 \pm 0.29^{c}$ & $4.30 \pm 0.10^{b}$ & $7.63 \pm 1.05^{\mathrm{b}}$ \\
\hline Fr-Bo & $10.54 \pm 0.82^{b}$ & $57.95 \pm 0.37^{\mathrm{g}}$ & $31.94 \pm 0.26^{\mathrm{c}}$ & $6.45 \pm 0.35^{\mathrm{c}}$ & $3.65 \pm 0.28^{b}$ \\
\hline Fr-Bo + VitE & $6.24 \pm 0.82^{\mathrm{a}}$ & $57.20 \pm 0.46^{\mathrm{g}}$ & $28.37 \pm 0.39^{b}$ & $3.25 \pm 0.25^{b}$ & $11.17 \pm 0.18^{b}$ \\
\hline Fr-Bo + CS & $9.69 \pm 0.16^{\mathrm{a}}$ & $46.57 \pm 0.65^{\mathrm{f}}$ & $28.83 \pm 1.08^{b}$ & $6.75 \pm 0.15^{c}$ & $17.83 \pm 1.86^{\mathrm{b}}$ \\
\hline Fr- Bo $+\mathrm{ZO}$ & $8.12 \pm 0.53^{\mathrm{a}}$ & $47.66 \pm 0.63^{f}$ & $39.33 \pm 0.43^{c}$ & $7.60 \pm 0.20^{c}$ & $5.40 \pm 1.26^{\mathrm{b}}$ \\
\hline Fr-Bo + AM & $9.20 \pm 0.52^{\mathrm{a}}$ & $45.48 \pm 0.15^{\mathrm{f}}$ & $35.36 \pm 0.13^{\mathrm{c}}$ & $7.70 \pm 0.20^{\mathrm{c}}$ & $11.45 \pm 0.08^{b}$ \\
\hline
\end{tabular}

Results are means \pm standard error $(\mathrm{n}=3)$. Means within each column with different superscripts differ significantly $(\mathrm{p}<0.05)$. Raw $=$ Raw meat; Raw $+\mathrm{VitE}=$ broiler reared with $200 \mathrm{UI}$ of vitamin $\mathrm{E}, \mathrm{Raw}+\mathrm{ZO}=$ broiler reared with $5 \mathrm{~g} / \mathrm{kg}$ of Zingiber officinale, Raw $+\mathrm{AM}=$ broiler reared with $5 \mathrm{~g} / \mathrm{kg}$ of Annona muricata; Raw $+\mathrm{CS}=$ broiler reared with $5 \mathrm{~g} / \mathrm{kg}$ of Camellia sinensis, $\mathrm{Bo}=$ Boiled meat, $\mathrm{Bo}+\mathrm{VitE}=$ Boiled meat reared with $200 \mathrm{UI}$ of vitamin $\mathrm{E} ; \mathrm{Bo}+\mathrm{ZO}=$ Boiled meat reared with $5 \mathrm{~g} / \mathrm{kg}$ of Zingiber officinale, $\mathrm{Bo}+\mathrm{AM}=$ Boiled meat reared with $5 \mathrm{~g} / \mathrm{kg}$ of Annona muricata, $\mathrm{Bo}+\mathrm{CS}=$ Boiled meat reared with $5 \mathrm{~g}$ of Camellia sinensis; $\mathrm{Fr}=$ Fried meat, $\mathrm{Fr}+\mathrm{VitE}=$ Fried meat reared with $200 \mathrm{UI}$ of vitamin $\mathrm{E}, \mathrm{Fr}+\mathrm{ZO}=$ Fried meat reared with $5 \mathrm{~g} / \mathrm{kg}$ of Zingiber officinale $; \mathrm{Fr}+\mathrm{AM}=$ Fried meat reared with $5 \mathrm{~g} / \mathrm{kg}$ of Annona muricata, $\mathrm{Fr}+\mathrm{CS}=$ Fried meat reared with5g/kg of Camellia sinensis, $\mathrm{Fr}-\mathrm{Bo}=$ Fried and boiled meat, $\mathrm{Fr}-\mathrm{Bo}+\mathrm{VitE}=$ Fried and boiled meat reared with $200 \mathrm{UI}$ of vitamin, Fr$\mathrm{Bo}+\mathrm{ZO}=$ Fried and boiled meat reared with $5 \mathrm{~g} / \mathrm{kg}$ of Zingiber officinale, $\mathrm{Fr}-\mathrm{Bo}+\mathrm{AM}=$ Fried and boiled meat reared with $5 \mathrm{~g} / \mathrm{kg}$ of Annona muricata and Fr-Bo+CS = Fried and boiled meat reared with $5 \mathrm{~g} / \mathrm{kg}$ of Camellia sinensis.

Malondialdehyde. However, all these acidities were lower than those recommended by FEDNA (1999) which was $8 \%$ for poultry fat and $4 \%$ for beef tallow and lard.

\subsection{Effect of culinary treatments on the proximate composition of broiler meat}

The effect of culinary treatments on the proximate composition of broiler thigh meat is presented in Table 2 . There was a significant $(p<0.05)$ reduction in moisture content between raw and cooked samples, in which a linear decrease $(p<0.05)$ in moisture content was observed as the cooking time and the temperature increase. The lowest value was obtained with the treatment Fr-Bo + VitE (6.24\%) and the highest value was by the treatment Raw+AM (74.66\%). These results revealed that thermal treatments help in decreasing the water content in meat, water might be displaced due to heat-induced protein denaturation during cooking (Juárez et al., 2010).According to Latip et al. (2013), heating techniques applied to meat products enhance its hygienic quality by inactivation of pathogenic microorganisms and improve its taste, flavor and shelf life.

For the protein content, there was a significant increased $(\mathrm{p}<0.05)$ in the protein content of broiler thigh meat after cooking treatments with high value observed in the combined treatments Fr-Bo (57.95\%) and FrBo+VitE $(57.20 \%)$ while the lowest values were obtained in raw sample (31.6\%) and raw sample supplied with powder of Annona muricata (26.88\%)(Table 2). This could be due to thermal treatment releasing water during cooking treatments, increase the aggregation and concentration of protein in meat. Latif (2010), showed a significant increase in protein content in marinated chicken breast muscle during frying $(29.50 \%)$, roasting $(22.60 \%)$ compared with the control $(18.65 \%)$. Also, for uncooked samples, we observed that rations supplemented with powders of Camellia sinensis and Zingiber officinale significantly increased $(\mathrm{p}<0.05)$ protein content of broiler meat. This was in agreement with findings of Kim et al. (2009), who showed that dietary supplementation with different levels of garlic bulb and garlic husk significantly increased the protein content of chicken thigh muscle compared with muscle from birds fed with non-supplemented diets. These values showed that broiler meat contained high levels of proteins, and can be used as an animal proteins source for human nutrition especially to enhance children 
growth.

Lipids content of broiler thigh meat exhibited a significant difference $(\mathrm{p}<0.05)$ among treatments (Table 2). Compared to raw samples, there was a considerable decrease in lipids content after cooking, in which a maximum decrease in fat was found in the treatment $\mathrm{Fr}+$ VitE $(25.14 \%)$ and a maximum increase was found in the treatment Raw+AM (55.24\%). High cooking temperature makes the meat juice run out leads to melted fat release from the surface. According to Braeckman et al. (2009), during thermal processing, water is usually lost either by evaporation through the crust or as drip, while fat is only lost exuded from the meat as a drip.

A similar finding has been showed by Gerber et al. (2009) when they studied the effect of cooking temperature and time on the fat content of meat. Also, Asmaa et al. (2015) showed a linear decreasing of the total fat content of sausage chicken with time at all investigated temperatures. Various investigations reported that longer cooking time at high temperature resulted in greater cooking, moisture and fat loss (Serrano et al., 2007; Sanghoon, 2011).The higher lipid content observed in this study indicates that broiler thigh meat may be classified as fatty meat (Feinberg et al., 1987) and this was due to the rations and to the fact that the skin was not removed in this study.

For the carbohydrates content (digestible and undigestible), there was a significant difference $(p<0.05)$ among cooked and uncooked treatments (Table 2). Fried treatments of broiler thigh meat revealed a high level of carbohydrate content (16.29-29.18\%); while the lowest value was obtained with the treatment Raw + CS $(0.47 \%)$. This might be due to thermal processing that released water and allowed concentration of carbohydrates in meat; also, it was also showed that broiler meat contained dietary fibers that are undigestible carbohydrate. These were in agreement with the findings of Tiwo et al. (2016) which showed an increase in carbohydrate content in cooked and fried freshwater fish produced in Cameroon compared to the raw sample.

Concerning the changes in ash content, there was a significant decrease $(p<0.05)$ after cooking treatment with the highest value obtained with the treatment Raw+CS (15.25\%) and the lowest value obtained with the treatment $\mathrm{Bo}+\mathrm{ZO}(0.70 \%)($ Table 2$)$. However, we observed that supplemented rations increased the ash content of broiler thigh meat compared to the raw sample. The values of ash content obtained in this study were greater than those obtained by Shirzadegan and Falahpour (2014) on thigh meat from broilers fed with dietary medicinal herb extract mixture that ranged from 2.69 to $4.94 \%$. The high concentration of ash in broiler thigh meat indicated a good source of minerals.

\subsection{Effect of culinary treatments on the mineral content of broiler meat}

The changes in the mineral composition of broiler thigh meat during processing are presented in Table 3. Broiler thigh meat contains important amount of macroelements, among which phosphorus, potassium, and calcium are the most represented and microelements among which there are iron and zinc. These mineral elements play important role in human health. They are implicated in several body functions such as enzymatic reactions, energy production, transmission of nerve impulses, and multiple biological reactions (Steinberg et al., 2003). For the iron content, there was a significant difference $(\mathrm{p}<0.05)$ among all the treatments. In general, the cooking treatments slightly decreased iron content of meat. It was showed that iron can be degraded if foods are cooked at a high temperature for too long (Hallberg et al., 1993). However, the values obtained in this study are greater than those obtained by Tiwo et al. (2016) on freshwater fishes of Cameroon.

The level of zinc ranged between 23.42 to $29.70 \mathrm{mg} /$ $\mathrm{kg}$ with high values obtained for the raw sample (Table 3). As observed above, cooking treatment decreased $(p<0.05)$ zinc content of broiler thigh meat compared to other treatments. These values were greater than those found by Njinkoue et al. (2016) on edible part of two Cameroonian marine fishes: Pseudotolithus elongatus (12.49 mg/kg) and Pseudotolithus elongatus (14.7 mg/ $\mathrm{kg})$.

Table 3 also revealed the level of macroelements of broiler thigh meat. It was observed that boiling significantly decreased $(p<0.05)$ the level of phosphorus and calcium in comparison to the other treatments with values ranging from 3531 to $6495 \mathrm{mg} / \mathrm{kg}$ for the treatments Bo and Fr+VitE and from 480 to $1920 \mathrm{mg} / \mathrm{kg}$ for Bo and Raw+VitE respectively for phosphorus and calcium levels. This was in agreement with findings of Tiwo et al. (2016) who showed that boiling decreased the level of phosphorus and calcium in two freshwater fish Clarias gariepinus and Cyprinus carpio. Due to the fact that calcium and phosphorus contents are not similar in all the samples, the $\mathrm{Ca} / \mathrm{P}$ ratios showed different values. According to Belitz et al. (2009), the $\mathrm{Ca} / \mathrm{P}$ ratio in food should be about 1 in order to enhance their absorption in the body. The results of our study were in agreement with findings of Njinkoue et al. (2016) on edible part of two Cameroonian marine fish.

The levels of sodium and potassium are presented in Table 3. Boiling significantly decreased $(p<0.05)$ the sodium and potassium levels compared to other 
Table 3. Changes in the mineral content of broiler meat during culinary treatments

\begin{tabular}{|c|c|c|c|c|c|c|c|}
\hline Samples & $\mathrm{Fe}(\mathrm{mg} / \mathrm{Kg})$ & $\mathrm{P}(\mathrm{mg} / \mathrm{Kg})$ & $\mathrm{Na}(\mathrm{mg} / \mathrm{Kg})$ & $\mathrm{K}(\mathrm{mg} / \mathrm{Kg})$ & $\mathrm{Zn}(\mathrm{mg} / \mathrm{Kg})$ & $\mathrm{Ca}(\mathrm{mg} / \mathrm{Kg})$ & $\mathrm{Mg}(\mathrm{mg} / \mathrm{Kg})$ \\
\hline Raw & $\begin{array}{c}356.50 \pm \\
6.50^{\mathrm{d}}\end{array}$ & $\begin{array}{c}4956.00 \pm \\
71.00^{\mathrm{e}}\end{array}$ & $\begin{array}{c}875.00 \pm \\
0.00^{\mathrm{d}}\end{array}$ & $\begin{array}{c}6354.00 \pm \\
0.00^{\mathrm{d}}\end{array}$ & $29.70 \pm 0.50^{\mathrm{b}}$ & $\begin{array}{c}600.00 \pm \\
40.00^{\mathrm{a}}\end{array}$ & $\begin{array}{c}182.50 \pm \\
36.50^{\mathrm{a}}\end{array}$ \\
\hline Raw + VitE & $\begin{array}{c}332.00 \pm \\
6.00^{\mathrm{b}}\end{array}$ & $\begin{array}{c}5625.50 \pm \\
28.50^{\mathrm{g}}\end{array}$ & $\begin{array}{c}1000.00 \pm \\
0.00^{\mathrm{f}}\end{array}$ & $\begin{array}{c}7483.00 \pm \\
2.00^{\mathrm{e}}\end{array}$ & $27.69 \pm 0.50^{b}$ & $\begin{array}{c}1920.00 \pm \\
80.00^{\mathrm{c}}\end{array}$ & $\begin{array}{c}243.00 \pm \\
0.00^{\mathrm{b}}\end{array}$ \\
\hline Raw + CS & $\begin{array}{l}341.00 \\
\pm .000^{\mathrm{c}}\end{array}$ & $\begin{array}{c}4485.50 \pm \\
28.50^{\mathrm{d}}\end{array}$ & $\begin{array}{c}750.00 \pm \\
0.00^{\mathrm{c}}\end{array}$ & $\begin{array}{c}5227.00 \pm \\
0.00^{\mathrm{c}}\end{array}$ & $28.45 \pm 0.25^{\mathrm{b}}$ & $\begin{array}{c}700.00 \pm \\
60.00^{\mathrm{a}}\end{array}$ & $\begin{array}{c}158.00 \pm \\
12.00^{\mathrm{a}}\end{array}$ \\
\hline $\mathrm{Raw}+\mathrm{ZO}$ & $\begin{array}{c}281.00 \pm \\
9.00^{\mathrm{a}}\end{array}$ & $\begin{array}{c}6138.50 \pm \\
28.50^{\mathrm{i}}\end{array}$ & $\begin{array}{c}1000.00 \pm \\
0.00^{\mathrm{f}}\end{array}$ & $\begin{array}{c}8604.00 \pm \\
4.00^{\mathrm{f}}\end{array}$ & $23.42 \pm 0.75^{\mathrm{a}}$ & $\begin{array}{c}680.00 \pm \\
40.00^{\mathrm{a}}\end{array}$ & $\begin{array}{c}195.50 \pm \\
1.50^{\mathrm{a}}\end{array}$ \\
\hline $\mathrm{Raw}+\mathrm{AM}$ & $\begin{array}{c}302.00 \pm \\
6.00^{\mathrm{b}}\end{array}$ & $\begin{array}{c}5298.00 \pm \\
14.00^{\mathrm{f}}\end{array}$ & $\begin{array}{c}747.50 \pm \\
2.50^{\mathrm{c}}\end{array}$ & $\begin{array}{c}6354.00 \pm \\
0.00^{\mathrm{d}}\end{array}$ & $25.18 \pm 0.50^{\mathrm{b}}$ & $\begin{array}{c}2200.00 \pm \\
120.00^{\mathrm{d}}\end{array}$ & $\begin{array}{c}449.50 \pm \\
60.50^{\mathrm{c}}\end{array}$ \\
\hline Bo & $\begin{array}{c}347.00 \pm \\
9.00^{\mathrm{c}}\end{array}$ & $\begin{array}{c}3531.00 \pm \\
71.00^{\mathrm{a}}\end{array}$ & $\begin{array}{c}500.00 \pm \\
0.00^{\mathrm{a}}\end{array}$ & $\begin{array}{c}2974.00 \pm \\
1.00^{\mathrm{a}}\end{array}$ & $28.95 \pm 0.75^{\mathrm{b}}$ & $\begin{array}{c}1800.00 \pm \\
40.00^{\mathrm{c}}\end{array}$ & $\begin{array}{c}437.50 \pm \\
48.50^{\mathrm{c}}\end{array}$ \\
\hline $\mathrm{Bo}+\mathrm{VitE}$ & $\begin{array}{c}335.00 \pm \\
9.00^{\mathrm{c}}\end{array}$ & $\begin{array}{c}4243.50 \pm \\
71.50^{\mathrm{c}}\end{array}$ & $\begin{array}{c}500.00 \pm \\
0.00^{\mathrm{a}}\end{array}$ & $\begin{array}{c}4100.00 \pm \\
0.00^{\mathrm{b}}\end{array}$ & $27.94 \pm 0.75^{\mathrm{b}}$ & $\begin{array}{c}480.00 \pm \\
0.00^{\mathrm{a}}\end{array}$ & $\begin{array}{c}206.50 \pm \\
12.50^{\mathrm{a}}\end{array}$ \\
\hline $\mathrm{Bo}+\mathrm{CS}$ & $\begin{array}{c}353.50 \pm \\
9.50^{\mathrm{c}}\end{array}$ & $\begin{array}{c}4143.50 \pm \\
28.50^{\mathrm{c}}\end{array}$ & $\begin{array}{c}505.00 \pm \\
5.00^{\mathrm{a}}\end{array}$ & $\begin{array}{c}4100.00 \pm \\
0.00^{\mathrm{b}}\end{array}$ & $29.45 \pm 0.75^{b}$ & $\begin{array}{c}480.00 \pm \\
80.00^{\mathrm{a}}\end{array}$ & $\begin{array}{c}121.50 \pm \\
24.50^{\mathrm{a}}\end{array}$ \\
\hline $\mathrm{Bo}+\mathrm{ZO}$ & $\begin{array}{c}329.00 \pm \\
9.00^{\mathrm{b}}\end{array}$ & $\begin{array}{c}3858.50 \pm \\
28.05^{\mathrm{b}}\end{array}$ & $\begin{array}{c}500.00 \pm \\
0.00^{\mathrm{a}}\end{array}$ & $\begin{array}{c}2973.00 \pm \\
0.00^{\mathrm{a}}\end{array}$ & $27.44 \pm 0.75^{\mathrm{b}}$ & $\begin{array}{c}560.00 \pm \\
0.00^{\mathrm{a}}\end{array}$ & $\begin{array}{c}218.50 \pm \\
24.50^{\mathrm{a}}\end{array}$ \\
\hline $\mathrm{Bo}+\mathrm{AM}$ & $\begin{array}{c}359.50 \pm \\
9.50^{\mathrm{d}}\end{array}$ & $\begin{array}{c}4685.00 \pm \\
57.00^{\mathrm{d}}\end{array}$ & $\begin{array}{c}622.50 \pm \\
2.50^{\mathrm{b}}\end{array}$ & $\begin{array}{c}5227.00 \pm \\
0.00^{\mathrm{c}}\end{array}$ & $29.95 \pm 0.75^{b}$ & $\begin{array}{c}640.00 \pm \\
0.00^{\mathrm{a}}\end{array}$ & $97.00 \pm 0.00^{\mathrm{a}}$ \\
\hline $\mathrm{Fr}$ & $\begin{array}{c}305.00 \pm \\
3.00^{\mathrm{b}}\end{array}$ & $\begin{array}{c}5896.50 \pm \\
14.50^{\mathrm{h}}\end{array}$ & $\begin{array}{c}750.00 \pm \\
0.00^{\mathrm{c}}\end{array}$ & $\begin{array}{c}6354.00 \pm \\
0.00^{\mathrm{d}}\end{array}$ & $25.43 \pm 0.25^{\mathrm{b}}$ & $\begin{array}{c}1640.00 \pm \\
120.00^{\mathrm{c}}\end{array}$ & $\begin{array}{c}705.00 \pm \\
73.00^{\mathrm{e}}\end{array}$ \\
\hline $\mathrm{Fr}+\mathrm{VitE}$ & $\begin{array}{c}287.00 \pm \\
3.00^{\mathrm{a}}\end{array}$ & $\begin{array}{c}6495.00 \pm \\
43.00^{\mathrm{j}}\end{array}$ & $\begin{array}{c}1000.00 \pm \\
0.00^{\mathrm{f}}\end{array}$ & $\begin{array}{c}7483.00 \pm \\
2.00^{\mathrm{e}}\end{array}$ & $23.92 \pm 0.25^{\mathrm{a}}$ & $\begin{array}{c}1160.00 \pm \\
200.00^{\mathrm{b}}\end{array}$ & $\begin{array}{c}364.50 \pm \\
72.50^{\mathrm{c}}\end{array}$ \\
\hline $\mathrm{Fr}+\mathrm{CS}$ & $\begin{array}{c}284.00 \pm \\
6.00^{\mathrm{a}}\end{array}$ & $\begin{array}{c}5853.50 \pm \\
28.50^{\mathrm{h}}\end{array}$ & $\begin{array}{c}875.00 \pm \\
0.00^{\mathrm{d}}\end{array}$ & $\begin{array}{c}7481.00 \pm \\
0.00^{\mathrm{e}}\end{array}$ & $23.67 \pm 0.50^{\mathrm{a}}$ & $\begin{array}{c}1440.00 \pm \\
80.00^{\mathrm{c}}\end{array}$ & $\begin{array}{c}121.50 \pm \\
24.50^{\mathrm{a}}\end{array}$ \\
\hline $\mathrm{Fr}+\mathrm{ZO}$ & $\begin{array}{c}302.00 \pm \\
6.00^{\mathrm{b}}\end{array}$ & $\begin{array}{c}6423.50 \pm \\
28.05^{\mathrm{j}}\end{array}$ & $\begin{array}{c}987.50 \pm \\
7.50^{\mathrm{e}}\end{array}$ & $\begin{array}{c}7482.00 \pm \\
1.00^{\mathrm{e}}\end{array}$ & $25.18 \pm 0.50^{b}$ & $\begin{array}{c}1620.00 \pm \\
60.00^{\mathrm{c}}\end{array}$ & $\begin{array}{c}498.00 \pm \\
12.00^{\mathrm{d}}\end{array}$ \\
\hline $\mathrm{Fr}+\mathrm{AM}$ & $\begin{array}{c}317.00 \pm \\
3.00^{\mathrm{b}}\end{array}$ & $\begin{array}{c}6210.00 \pm \\
43.00^{\mathrm{i}}\end{array}$ & $\begin{array}{c}875.00 \pm \\
0.00^{\mathrm{d}}\end{array}$ & $\begin{array}{c}7481.00 \pm \\
0.00^{\mathrm{e}}\end{array}$ & $26.44 \pm 0.25^{b}$ & $\begin{array}{c}1340.00 \pm \\
20.00^{\mathrm{b}}\end{array}$ & $\begin{array}{c}510.50 \pm \\
24.50^{\mathrm{d}}\end{array}$ \\
\hline Fr-Bo & $\begin{array}{c}323.00 \pm \\
3.00^{\mathrm{b}}\end{array}$ & $\begin{array}{c}5797.00 \pm \\
57.00^{\mathrm{h}}\end{array}$ & $\begin{array}{c}747.50 \pm \\
2.50^{\mathrm{c}}\end{array}$ & $\begin{array}{c}5228.00 \pm \\
1.00^{\mathrm{c}}\end{array}$ & $26.94 \pm 0.25^{\mathrm{b}}$ & $\begin{array}{c}1360.00 \pm \\
0.00^{\mathrm{b}}\end{array}$ & $\begin{array}{c}534.50 \pm \\
48.50^{\mathrm{d}}\end{array}$ \\
\hline $\begin{array}{c}\text { Fr-Bo }+ \\
\text { VitE }\end{array}$ & $\begin{array}{c}314.00 \pm \\
6.00^{\mathrm{b}}\end{array}$ & $\begin{array}{c}5668.50 \pm \\
71.50^{\mathrm{g}}\end{array}$ & $\begin{array}{c}625.00 \pm \\
0.00^{\mathrm{b}}\end{array}$ & $\begin{array}{c}5227.00 \pm \\
0.00^{\mathrm{c}}\end{array}$ & $26.18 \pm 0.50^{\mathrm{b}}$ & $\begin{array}{c}1800.00 \pm \\
40.00^{\mathrm{c}}\end{array}$ & $\begin{array}{c}729.00 \pm \\
49.00^{\mathrm{d}}\end{array}$ \\
\hline Fr-Bo + CS & $\begin{array}{c}305.00 \pm \\
3.00^{\mathrm{b}}\end{array}$ & $\begin{array}{c}5340.50 \pm \\
28.05^{\mathrm{f}}\end{array}$ & $\begin{array}{c}750.00 \pm \\
0.00^{\mathrm{c}}\end{array}$ & $\begin{array}{c}6354.00 \pm \\
0.00^{\mathrm{d}}\end{array}$ & $25.43 \pm 0.25^{\mathrm{b}}$ & $\begin{array}{c}1440.00 \pm \\
80.00^{\mathrm{c}}\end{array}$ & $\begin{array}{c}668.00 \pm \\
12.00^{\mathrm{e}}\end{array}$ \\
\hline Fr- Bo $+\mathrm{ZO}$ & $\begin{array}{c}332.00 \pm \\
6.00^{\mathrm{b}}\end{array}$ & $\begin{array}{c}5611.50 \pm \\
14.50^{\mathrm{g}}\end{array}$ & $\begin{array}{c}625.00 \pm \\
0.00^{\mathrm{b}}\end{array}$ & $\begin{array}{c}4100.00 \pm \\
0.00^{\mathrm{b}}\end{array}$ & $27.69 \pm 0.50^{\mathrm{b}}$ & $\begin{array}{c}1780.00 \pm \\
60.00^{\mathrm{c}}\end{array}$ & $\begin{array}{c}413.00 \pm \\
0.00^{\mathrm{c}}\end{array}$ \\
\hline Fr-Bo + AM & $\begin{array}{c}311.00 \pm \\
9.00^{\mathrm{b}}\end{array}$ & $\begin{array}{c}4243.50 \pm \\
71.50^{\mathrm{c}}\end{array}$ & $\begin{array}{c}1375.00 \pm \\
0.00^{\mathrm{g}}\end{array}$ & $\begin{array}{c}5227.00 \pm \\
0.00^{\mathrm{c}}\end{array}$ & $25.93 \pm 0.75^{b}$ & $\begin{array}{c}1640.00 \pm \\
120.00^{\mathrm{c}}\end{array}$ & $\begin{array}{c}340.50 \pm \\
48.50^{\mathrm{c}}\end{array}$ \\
\hline
\end{tabular}

Results are means \pm standard error $(n=3)$. Means within each column with different superscripts differ significantly $(\mathrm{p}<0.05)$. Raw $=$ Raw meat; Raw + VitE $=$ broiler reared with 200 UI of vitamin E. Raw $+Z O=$ broiler reared with $5 \mathrm{~g} / \mathrm{kg}$ of Zingiber officinale. Raw $+\mathrm{AM}=$ broiler reared with $5 \mathrm{~g} / \mathrm{kg}$ of Annona muricata; $\mathrm{Raw}+\mathrm{CS}=$ broiler reared with $5 \mathrm{~g} / \mathrm{kg}$ of Camellia sinensis. $\mathrm{Bo}=$ Boiled meat. Bo+VitE $=$ Boiled meat reared with $200 \mathrm{UI}$ of vitamin $\mathrm{E} ; \mathrm{Bo}+\mathrm{ZO}=$ Boiled meat reared with $5 \mathrm{~g} / \mathrm{kg}$ of Zingiber officinale. Bo $+\mathrm{AM}=$ Boiled meat reared with $5 \mathrm{~g} / \mathrm{kg}$ of Annona muricata. Bo $+\mathrm{CS}=$ Boiled meat reared with $5 \mathrm{~g}$ of Camellia sinensis; $\mathrm{Fr}=$ Fried meat. Fr $+\mathrm{VitE}=$ Fried meat reared with $200 \mathrm{UI}$ of vitamin $\mathrm{E} . \mathrm{Fr}+\mathrm{ZO}=$ Fried meat reared with5g/ $\mathrm{kg}$ of Zingiber officinale; $\mathrm{Fr}+\mathrm{AM}=$ Fried meat reared with $5 \mathrm{~g} / \mathrm{kg}$ of Annona muricata. $\mathrm{Fr}+\mathrm{CS}=$ Fried meat reared with $5 \mathrm{~g} / \mathrm{kg}$ of Camellia sinensis. Fr-Bo $=$ Fried and boiled meat. Fr-Bo+VitE $=$ Fried and boiled meat reared with 200 UI of vitamin. Fr$\mathrm{Bo}+\mathrm{ZO}=$ Fried and boiled meat reared with $5 \mathrm{~g} / \mathrm{kg}$ of Zingiber officinale. Fr-Bo $+\mathrm{AM}=$ Fried and boiled meat reared with $5 \mathrm{~g} / \mathrm{kg}$ of Annona muricata and Fr-Bo+CS = Fried and boiled meat reared with $5 \mathrm{~g} / \mathrm{kg}$ of Camellia sinensis.

treatments. Their values ranged from 500 to $1375 \mathrm{mg} / \mathrm{kg}$ respectively for the treatments Bo and Fr-Bo+AM for sodium level; while for potassium level, they ranged from 2973 to $8604 \mathrm{mg} / \mathrm{kg}$ for the treatments Bo+ZO and $\mathrm{Raw}+\mathrm{ZO}$ respectively. These results were similar to those of Tiwo et al. (2016) who showed that boiling decreased the level of sodium and phosphorus in freshwater fish Cyprinus carpio produced in Batie, West-
Cameroon. Also, the sodium and potassium contents were not similar in all the samples and the $\mathrm{Na} / \mathrm{K}$ ratios showed different values. According to $\mathrm{Bu}$ et al. (2012) and Perez et al. (2014), the $\mathrm{Na} / \mathrm{K}$ ratio in food should be less than 1 as a good indicator for human health, especially in the case of cardiovascular disease prevention. 
Concerning the level of magnesium in broiler thigh meat, there was a significant difference $(\mathrm{p}<0.05)$ between the samples. The level of magnesium ranged between $97 \mathrm{mg} / \mathrm{kg}$ (Bo+AM) to $729 \mathrm{mg} / \mathrm{kg}$ (Fr-Bo+VitE) (Table 3). Overall, the values obtained in this study were lower than those shown by Tiwo et al. (2016) on cooked and uncooked freshwater fish produced in Batie, Cameroon.

\section{Conclusion}

The objective of this study was to evaluate the effects of feeding system and cooking treatments on the lipids quality, proximate composition and mineral content of broiler meat fed with powders of three natural plants. Results revealed that food supplementation with dry powder of Annona muricata flower at $0.5 \%$ limited the formation of hydroperoxide and malondialdehyde in oil extracted from broiler meat during frying. Also, all the treatments significantly reduced the iodine value of oils extracted from broiler meat. The combined treatments increased acid value of fat. Rations supplemented with powders of Camellia sinensis, Annona muricata and Zingiber officinale also enhanced the proximate composition and mineral content of uncooked and cooked broiler meat.

\section{Conflict of interest}

The authors declare that there are no conflicts of interest.

\section{Acknowledgments}

We would like to acknowledge Prof. Dr. Womeni Hilaire and Dr. Mumbe Herve for their technical support and continuous encouragement throughout this research.

\section{References}

Ahn, DU., Nam, K.C. and Lee E.J. (2009). Lipid oxidation and flavor. Applied Muscle Biology and Meat Science, 12(2), 27 - 46. https:// doi.org/10.1201/b15797-13

Altmann, H.J., Grunow, W., Mohr, U., RichterReichhelm, H.B. and Wester, P.W. (1986). Effects of BHA and related phenols on the forestomach of rats. Food Chemistry and Toxicology, 24(10-11), 1183-1188. https://doi.org/10.1016/0278-6915(86) 90306-6

American Oil Chemist's Society (AOCS). (2003). Official methods and recommended practices of the American Oil Chemist's Society. 5th ed. USA: AOCS

Asmaa, A.A., Zzaman, W. and Tajul, A.Y. (2015). Effect of superheated steam cooking on fat and fatty acid composition of chicken sausage. International Food Research Journal, 22(2), 598-605.

Association of Official Analytical Chemists (AOAC). (1990). Official methods of analysis. $16^{\text {th }}$ ed. Washington, D.C., USA: AOAC

Association of Official Analytical Chemists (AOAC). (1999). Official methods of analysis. $21^{\text {st }}$ ed. Washington, D.C., USA: AOAC

Barroeta, A. (2007). Nutritive value of poultry meat: relationship between vitamin E and PUFA. World's Poultry Science Journal, 63(2), 277-284. https:// doi.org/10.1017/S0043933907001468

Belitz, H.D., Crosch, W. and Schieberle, P. (2009). Food Chemistry-Google Books Result - Technology and Engineering, p. 424-528. Retrieved on January 9, 2018 from: https://books.google.cm/books? isbn $=3540699333$.

Bhagwat, S., Haytowitz, D.B. and Holden, J.M. (2013). USDA database for the flavonoid content of selected foods. Release 3.1. Department of Agriculture. Agricultural Research Service. Retrieved from Nutrient Data Laboratory Home Page: http:// www.ars.usda.gov/nutrientdata/flav

Bligh, E.G. and Dyer, W.J. (1959). A Rapid method for total lipid extraction and purification. Canadian Journal of Biochemistry and Physiology, 37(8), 911917. https://doi.org/10.1139/o59-099

Bodas, R., Prieto, N., López-Campos, O., Giráldez, F.J. and Andrés, S. (2011). Naringin and vitamin E influence the oxidative stability and lipid profile of plasma in lambs fed fish oil. Research in Veterinary Science, 91(1), 98 - 102. https://doi.org/10.1016/ j.rvsc.2010.07.028.

Boler, D.D., Gabriel, S.R., Yang, H., Balsbaugh, R., Mahan, D.C., Brewer, M.S., McKeith, F.K. and Killefer, J. (2009). Effect of different dietary levels of natural-source vitamin $\mathrm{E}$ in grow-finish pigs on pork quality and shelf life. Meat Science, 83(4), 723730. https://doi.org/10.1016/j.meatsci.2009.08.012

Botsoglou, E., Govaris, A., Ambrosiadis, I., Fletourisc, D. and Papageorgioud, G. (2014). Effect of olive leaf (Olea europea L.) extracts on protein and lipid oxidation in cooked pork meat patties enriched with n-3 fatty acids. Journal of Science and Food Agriculture, 94(2), 227 - 234. https:// doi.org/10.1002/jsfa.6236

Botsoglou, N.A., Fletouris, D.J., Florou-Paneri, P., Christaki, E. and Spais, A.B. (2003). Inhibition of lipid oxidation in long-term frozen stored chicken meat by dietary oregano essential oil and $\alpha$ tocopheryl acetate supplementation. Food Research 
International, 36(3), 207-213. https:// doi.org/10.1016/S0963-9969(02)00095-9

Braeckman, L., Ronsse, F., Hidalgo, P.C. and Pieters, J. (2009). Influence of combined IR grilling and hot air cooking conditions on moisture and fat content, texture and colour attributes of meat patties. Journal of Food Engineering, 93(4), 437-443. https:// doi.org/10.1016/j.jfoodeng.2009.02.009

Bu, S.Y., Kang, M.H., Kim, E.-J. and Choi, M.K. (2012). Dietary intake ratios for calciumtophosphorus and sodium-to-potassium are associated with serum lipid levels in healthy Korean adults. Preventive Nutrition and Food Science, 17 (2), 93-100. https://doi.org/10.3746/ pnf.2012.17.2.093

Camo, J., Beltrán, J.A. and Roncalés, P. (2008). Extension of the display life of lamb with an antioxidant active packaging. Meat Science, (80), 1086-1091. j.meatsci.2008.04.031

Chen, P., Ma, Q.G., Ji, C., Zhang, J.Y., Zhao, L.H., Zhang, Y. and Jie, Y.Z. (2011). Dietary lipoic acid influences antioxidant capability and oxidative status of broilers. International Journal of Molecular Sciences, 12(12), 8476-8488. https:// doi.org/10.3390/ijms 12128476

Chouliara, E., Karatapanis, A., Savvaidis, I.N. and Kontominas, M. (2007). Combined effect of oregano essential oil and modified atmosphere packaging on shelf-life extension of fresh chicken breast meat. stored at $4^{\circ} \mathrm{C}$. Food Microbiology, 24(6), 607-917. https://doi.org/10.1016/j.fm.2006.12.005

CODEX. (2015). Standard for Named Animal Fats. (CODEX Stan 211 - 1999). Rome: CODEX Alimentarius

D'Arrigo, M., Hoz, L., Lopez-Bote, C.J., Cambero, I., Pin, C., Rey, A.I. and Ordóñez, J.A. (2002). Effect of dietary linseed oil and $\alpha$-tocopherol on selected properties of pig fat. Canadian Journal of Animal Science, 82(3), 339-346. https://doi.org/10.4141/ A01-095

Draper, H.H. and Hadley, M. (1990). Malondialdehyde determination as index of lipid peroxidation. Methods. Enzymology, 186, 421-431. http:// dx.doi.org/10.1016/0076- 6879(90)86135-I.

El-Ghorab, H., Nauman, M., Anjum, F.M., Hussain, S. and Nadeem, M. (2010). Comparative study on chemical composition and antioxidant activity of ginger (Zingiber officinale) and cumin (Cuminum cyminum). Journal of Agricultural and Food Chemistry, 58(14), 8231-8237. https:// doi.org/10.1021/jf101202x
Ennajar, M. Bouajila J., Labrini, A., Mathieu, F., Abderraba, M., Raies, A. and Romdhane, M. (2009). Chemical composition and antimicrobial and antioxidant activities of essential oils and various extracts of Juniperns phoenicea L. (Cupressacees). Journal of Food Sciences, 74, 364 - 371. https:// doi.org/10.1111/j.1750-3841.2009.01277.x

Feinberg, M., Favier, J.C., Ireland-Ripert, J. and Ciqual. (1987). General catalogue of foods: fat food table composition. France: National Institute of Agronomic Research.

Frega, N., Mozzon, M. and Lercker, G. (1999). Effect of free fatty acids on the oxidative stability of vegetable oils. Journal of American Oil Chemists Society, 76 (3), 325-329. https://doi.org/10.1007/s11746-9990239-4

Fundación Española para el Desarrollo de la Nutrición Animal (FEDNA). (1999). Normas FEDNA para la formulación de piensos compuestos. Madrid: Ediciones Peninsular.

Gerber, N., Scheeder, M.R.L. and Wenk, C. (2009). The influence of cooking and fat trimming on the actual nutrient intake from meat. Meat Science, 81(1), 148154. https://doi.org/10.1016/j.meatsci.2008.07.012

Giannenas, I.A., Florou-Paneri, P., Papazahariadou, M., Botsoglou, N.A., Christaki, E. and Spais, A.B. (2005). Effect of diet supplementation with ground oregano on the performance of broiler chickens challenged with Eimeriatenella. Archiv fur Geflugelkunde, 68(6), 247-252.

Goliomytis, M., Tsoureki, I.D., Simitzis, P.E., Charismiadou, M.A., Hager-Theodorides, A.L. and Deligeorgis, S.G. (2014). The effects of quercetin dietary supplementation on broiler growth performance, meat quality and oxidative stability. Poultry Science, 93(8), 1-6. https://doi.org/10.3382/ ps.2013-03585

Greene, B.E. and Cumuze, T.H. (1982). Relationship between TBA numbers and inexperienced panelist's assessments of oxidized flavor in cooked beef. Journal of Food Science, 47, 52-58. https:// doi.org/10.1111/j.1365-2621.1982.tb11025.x

Haak, L., Raes, K., Smet, K., Claeys, E., Paelinck, H. and De Smet S. (2009). Effect of dietary antioxidant and fatty acid supply on the oxidative stability of fresh and cooked pork. Meat Science, 74, 476-486. https://doi.org/10.1016/j.meatsci.2006.04.018

Hallberg, L., Rossander-Hulthén, L., Brune, M. and Gleerup, A. (1993). Inhibition of haem-iron absorption in man by calcium. British Journal of Nutrition, 69, 533-540. https://doi.org/10.1079/ BJN19930053 
Hernandez, P., Navarro, J.L. and Toldra, F. (1999). Lipids of pork meat as affected by various cooking techniques. Food Science and Technology International, 5(6), 501-508. https:// doi.org/10.1177/108201329900500608

International Dairy Federation (IDF). (1991). Milk fat Determination of peroxide value. IDF 74A. Brussels, Belgium: IDF

Juárez, M., Failla, S., Ficco, A., Peña, F., Avilés, C. and Polvillo, O. (2010). Buffalo meat composition as affected by different cooking methods. Food and Bioproducts Processing, 88(2-3), 145-148. https:// doi.org/10.1016/j.fbp.2009.05.001

Juntachote, T., Berghofer, E., Siebenhandl, S. and Bauer. F. (2007). Antioxidative effect of added dried holy basil and its ethanolic extracts on susceptibility of cooked ground pork to lipid oxidation. Food Chemistry, 100(1), 129 -135 .

j.foodchem.2005.09.033

Kim, Y.J., Jin, S.K. and Yang, H.S. (2009). Effect of dietary garlic bulb and husk on the physiochemical properties of chicken meat. Poultry Science, 88(1), 398-405. https://doi.org/10.3382/ps.2008-00179

Labuza, T.P. (1974). Effect of dehydration and storage on nutrient retention in foods. Food Technology, 27 (1), 20-26.

Lahucky, R., Nuernberg, K., Kovac, L., Bucko, O. and Nuernberg, G. (2010). Assessment of the antioxidant potential of selected plant extracts - in vitro and in vivo experiments on pork. Meat Science, 85(4), 779784. https://doi.org/10.1016/j.meatsci.2010.04.004

Latif, S.S. (2010). Effect of marination on the quality characteristics and microstructure of chicken breast meat cooked by different methods. Lucrari Stiintifice, 53, 753-764

Latip, L.D., Zzaman, W. and Yang, T.A. (2013). Effect of chilled-frozen storage on the physico-chemical, microbial and sensory quality of farmed bighead carp (Hypophthalmichthys nobilis). Journal of Fisheries and Aquatic Science, 8(6), 686-696. https://doi.org/10.3923/jfas.2013.686.696

Li, W.J., Zhao, G.P. Chen, J.L., Zheng, M.Q. and Wen, J. (2009). Influence of dietary vitamin E supplementation on meat quality traits and gene expression related to lipid metabolism in the Beijingyou chicken. British Poultry Science, 50(2), 188198. https://doi.org/10.1080/00071660902755409

Lin, H.S., Lee, J.Y. and Ke, B.C. (2011). Effect of Cooking Method and Storage on the Quality of Minced Pork. Journal of Agricultural Science and Technology, 1, 1249-1256.
Lopez-Bote, C.J., Gray, J.I., Gomaa, E.A. and Flegal, C.J. (1998). Effect of dietary administration of oil extracts from rosemary and sage on lipid oxidation in broiler meat. British Poultry Science, 39, 235-240. https://doi.org/10.1080/00071669889187

Mohamed, A., Jamilah, B., Abbas, K. and Rahman, R.A. (2008). A review on lipid oxidation of meat in active and modified atmosphere packaging and usage of some stabilizers. Journal of Food, Agriculture and Environment, 6(3 and 4), 7681.

Njinkoue, J.M., Gouado, I., Tchoumbougnang, F., Yanga N.J.H., Ndinteh, D.T., Fomogne-Fodjo, C.Y. and Schweigert F.J. (2016). Proximate composition, mineral content and fatty acid profile of two marine fishes from Cameroonian coast: Pseudotolithus typus (Bleeker, 1863) and Pseudotolithus elongatus (Bowdich, 1825). NFS Journal, 4, 27-31. https:// doi.org/10.1016/j.nfs.2016.07.002

Onyeike, E.N., Anyalogbu, E.A. and Monanu, M.O. (2015). Effect of heat processing on the proximate composition and energy values of African walnut (Plukenetia conophora) and African Elemi (Canarium schweinfurthii) consumed as masticatories in Nigeria. International Journal of Scientific and Technology Research, 4, 295-301.

Perez, V., Ellen, T. and Chang, V. Sodium-to-potassium ratio and blood pressure, hypertension, and related factors. Advances in Nutrition, 5(6), 712-741. https://doi.org/10.3945/an.114.006783

Rehman, Z., Salariya, A.M. and Habib, F. (2003). Antioxidant activity of ginger extract in sunflower oil. Journal of Agriculture and Food Chemistry, 83 (7), 624-629. https://doi.org/10.1002/jsfa.1318

Sanghoon, K.O., Sang-Ho, Y., Suyong, L., Seongho, C., Kwang-Hwa, K. and Rina, H. (2011). Effect of long low temperature-short high temperature cooking cycle on physicochemical properties of beef. Food Science and Technology Research, 17(1), 11-16.

Schwartzkopf-Genswein, K.S., Faucitano, L., Dadgar, S., Shand P., González L.A. and Crowe T.G. (2012). Road transport of cattle. swine and poultry in North America and its impact on animal welfare. carcass and meat quality: A review. Meat Science, 92, 227243. https://doi.org/10.1016/j.meatsci.2012.04.010

Serrano, A., Librelotto, J., Cofrades, S., Sánchez-Muniz, F.J. and Jiménez-Colmenero, F. (2007). Composition and physicochemical characteristics of restructured beef steaks containing walnuts as affected by cooking method. Meat Science, 77(3), 304-313. https://doi.org/10.1016/j.meatsci.2007.03.017

Shermer, W.D. (1990). Effects of oxidation on the 
quality of ingredients and feed of poultry. $37^{\circ}$ Maryland Nutrition Conference. Maryland, United State of America.

Shirzadegan, K. and Falahpour, P. (2014). The physicochemical properties and antioxidative potential of raw thigh meat from broilers fed a dietary medicinal herb extract mixture. Open Veterinary Journal, 4(2), 69-77.

Sohaib, M., Anjum, F.M., Arshad, M.S., Imran, M., Imran, A. and Hussain, S. (2017). Oxidative stability and lipid oxidation flavoring volatiles in antioxidants treated chicken meat patties during storage. Lipids in Health and Disease, 16(27), 1-10. http// doi 10.1186/s12944-017-0426-5.

Sohaib, M., Anjum, F.M., Khan, M.I., Arshad, M.S. and Shahid, M. (2012). Enhancement of lipid stability of broiler breast meat and meat products fed on $\alpha$-lipoic acid and $\alpha$-tocopherol acetate supplemented feed. Lipids Health Disease, 11, $57 . \quad$ https:// doi.org/10.1186/1476-511X-11-57

Sohaib, M., Sadiq, B.M., Shabbir, M.A. and Shahid, M. (2015). Lipid stability, antioxidant potential and fatty acid composition of broilers breast meat as influenced by quercetin in combination with $\alpha$ tocopherol enriched diets. Lipids in Health and Disease, 14, 61. https://doi.org/10.1186/s12944-0150058-6

Song, S., Zhang, X., Hayat, K., Liu, P., Chengsheng, J., Shuqin, X., Xiao, Z., Tian H. and Niu. Y. (2010). Formation of the beef flavour precursors and their correlation with chemical parameters during the controlled thermal oxidation of tallow. Food Chemistry, 115(3), 435-443.

Steinberg, F.M., Bearden, M.M. and Keen, C.L. (2003). Cocoa and chocolate flavonoids: Implications for cardiovascular health. Journal of the American Dietetic Association, 103(2), 215-223. https:// doi.org/10.1053/jada.2003.50028

Tang, S.Z., Kerry, J.P., Sheeham, D., Buckley, D.J. and Morrissey, P.A. (2001). Antioxidative effect of dietary tea catechins on lipid oxidation of long-term frozen stored chicken meat. Meat Science, 57(3), 331 -336. https://doi.org/10.1016/S0309-1740(00)001121

Tiwo, T.C., Womeni, H.M., Tchoumbougnang, F., Ndomou, S. and Linder M. (2016). Effects of culinary treatments on the in vitro nutritional quality and the functional properties of freshwater fishes of Cameroon: Clarias gariepinus, Heterotis niliticus, Cyprinus carpio and Oreochromis niloticus. International Journal of Biotechnology and Food Science, 4(4), 1-13. https://doi.org/10.1016/ j.nfs.2016.03.002
Womeni, H.M., Djikeng, F.T., Anjaneyulu, B., Karuna, M.S.L., Prasad, R.B.N. and Linder, M. (2016). Oxidative stabilization of RBD palm olein under forced storage conditions by old Cameroonian green tea leaves methanolic extract. NFS Journal, 3, 33-40. http://dx.doi.org/10.1016/j.nfs.2016.03.002

Womeni, H.M., Tonfack, D.F., Prabhakar, I.N.S.S., Lakshmi, K.M.S., Narayana, P.R.B., and Linder. M. (2016). Valorization of soursop flowers (Annona muricata L.) as potent source of natural antioxidants for stabilization of palm olein during accelerated storage. Food Science and Nutrition, 4(6), 802-810. https://doi.org/10.1002/fsn3.349 